Spain

silvia.manessi@usal.es

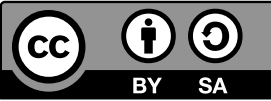

\title{
EQUALITY AND DIVERSITY MANAGEMENT INSIDE THE INSTITUTIONS OF THE EUROPEAN UNION: A CORPUS LINGUISTIC ANALYSIS OF THEIR HUMAN RESOURCES LEGAL FRAMEWORK
}

During the last few years, EU institutions have made great strides towards fostering the principles of equality and diversity among their staff members: EU civil servants are being exposed to awareness-raising campaigns and are systematically involved in the implementation of staff policies aimed at increasing their sensitivity to diversity and inclusion. Since 2000, the European Charter of Fundamental Rights (European Parliament, 2000) has been a legally binding text for the Member States of the European Union and the European institutions themselves.

Nevertheless, a first reading of the internal regulations and implementing rules related to staff management inside the EU institutions shows that they are written in a language that is not completely consistent with the EU Charter of Fundamental Rights and its values of equality and diversity. The rationale of this paper starts from this perspective, and a first preliminary qualitative assessment of the language used in the Human Resources legal framework of EU institutions.

The first consideration, which is very evident, is that most of the current HR implementing provisions are simply not gender-neutral. The Staff Regulations still include a caveat wording to this regard, as Article 1c states that:

Any reference in these Staff Regulations to a person of the male sex shall be deemed also to constitute a reference of a person to the female sex, and viceversa unless the context clearly indicates otherwise. (European Council, 1962).

As the plural form might be used in the English language, the argument for using only the masculine pronoun does not seem to be valid. Moreover, other key terms, which are used in the Staff Regulations, could be more gender-neutral: reference to 'chairman' instead of 'chairperson' can be found in different occurrences in the Staff Regulation. 
Moreover, looking into the family sphere of the EU Institutions' staff members, and in the context of granting contractual rights and entitlements, the Staff Regulations still include non-inclusive language, with the use of terms such as 'marriage', even where the legal framework applies to a non-marital partnership. Notwithstanding what is stated in Article 1.d, whereby "non-marital partnerships shall be treated as marriage provided that all the conditions listed in Article 1(2)(c) of Annex VII are fulfilled" (European Council, 1962), the Staff Regulations have nine occurrences where the term 'wife' and seven where the term 'husband' are still included in the text. The term 'marriage' is also used in different instances. While state that a non-marital partnership is compared to marriage with regard to the application of entitlements in the Staff Regulations, a more cohesive use of the language might reinforce the principle of equality, vis-à-vis persons who do not have access to legal marriage in all Member States, and thus change the mindset of the civil servants who are all affected by these regulations.

Some additional preliminary considerations also relate to the use of the term 'disabled', which is in different instances present in the EU HRM legal framework. The 2006 UN Convention on the Rights of Persons with Disabilities (UN General Assembly, 2007) refers to 'person with a disability' instead of disabled person, to underline that a person is not disabled but has a disability. The Convention was signed by all twenty-eight European Member States (including the UK, before leaving) and, at the time of writing this paper, has been ratified by twenty-five. In 2010, the European Union also ratified the Convention, and it now plays a leading role in the monitoring framework for its implementation among the EU institutions. The definition of a person with a disability in the UN Convention reads as follows:

Persons with disabilities include those who have long-term physical, mental, intellectual or sensory impairments, which in interaction with various barriers may hinder their full and effective participation in society on an equal basis with others. (UN General Assembly, 2007)

This wording is deemed fundamental in changing the mindset of people without a disability: although the Staff Regulations take on board this definition and include it in Article 1d, in later articles of the consolidated version of the text the term 'disabled' still occurs.

\subsection{Research Hypothesis}

With regard to the preliminary qualitative assessment mentioned above, this paper aims to shed more light on the use of English language in the HRM context of the EU institutions. This has been done by analysing the legal basis of staff management in the context of equality and diversity management among EU civil servants. This research 
hypothesises that the language of legal texts and policies of the European institutions related to staff management is not inclusive, and it is not completely in line with the idea of fostering equality and diversity.

In order best to address the research questions related to the discourse of equality in the EU institutions, and at the same time considering the preliminary hypothesis as outlined above, this investigation is being carried out and developed by taking stock of the relevant linguistic features (Baker, 2006), included in staff legal provisions applicable to EU civil servants. In particular, it entails the creation and linguistic analysis of a corpus of regulations and rules related to the management of human resources working for the different EU institutions, hereinafter called the EU HRM Legal Corpus (Hunston, 2002; Baker, 2010; Crawford \& Csomay, 2016).

\subsection{Literature review}

Corpora analysis have been the subject of different studies in various linguistics fields, recent publications include studies in lexical semantics (Stubbs, 2001), applied linguistics, (Hyland, Huat, \& Handford, 2012), sociolinguistics (Hunston, 2002; Baker, 2010; Crawford \& Csomay, 2016) and discourse analysis (Baker, 2006).

Concerning the study of linguistics features related to equality and diversity, a number of studies have been supported by the use of corpora over the last few decades. Of particular importance for this research are the studies of scholars in the lexicological field, in particular those related to gender studies. Kjellmer (1986) was the first scholar to analyse the use of the terms 'man/men' and 'woman/women', together with the occurrence of the masculine and feminine pronouns, to unravel the masculine bias in American and British English in both the Lancaster-Oslo/Bergen and Brown corpora. Similar studies followed the lexicological stream highlighted by Kjellmer (Eckert \& McConnellGinet, 2003; Pearce, 2008; Vefali \& Erdentuğ, 2010; Hankivsky, 2013; Taylor, 2013; Moon, 2014; Baker, 2014). They defined and analysed the different use of the masculine and feminine forms with a focus on the biases which stem from the use of these forms in a given corpus, which is also one of the aims of the current paper.

At the same time, this paper benefits from the work of scholars in linguistic fields related to equality and diversity studies (Tatli, 2011), in particular studies related to the language and the discourse around the LGBTI community (Baker, 2005 and 2018; Hord, 2016), persons with a disability (Grue, 2014) and ageist language (Mautner, 2007; Hummert, Garstka, Ryan, \& Bonnesen, 2004).

A key element of this paper is the corpus analysis of the corporate and workplace discourse (Bathia, 1993; Alvesson \& Karreman, 2000; Cooren, 2004; Hatch \& Cunliffe, 2006; Morgan, 2006; Bréda, Delattre \& Ocler, 2008; Maurel, 2008; Manuti \& Minnini, 2015), since the focal linguistic patterns happen in a work-related setting, i.e. EU institutions. Since the language analysed relates to corporate legal discourse, studies on such a genre 
framework (Bathia, 1983; Marmor, 2008; Gibová, 2011), including those that focused on an EU setting (Breidbach, 2003; Barone, 2005; Trebits, 2008), are the basis of this paper.

Another important element of this study is the issue of the EU civil servants' identity building; to support the corpus analysis in this field different studies have been taken into consideration, in particular, those related to the development of participant's identities in a multilingual and multicultural setting (Searle, 1995; Edwards, 2009; Cenoz, 2013; Holmes, 2015). METHODOLOGICAL FRAMWORK AND PRELIMINARY RESULTS

The issues touched upon by this paper are mainly related to two different aspects. In the first place, an analysis of the main features of the English language used in the corpus. In the second place, a more specific examination of the terminology related to equality and diversity management - both from an overall point of view and, more specifically, regarding four different features: LGBTI issues, gender mainstreaming, rights of the elderly and rights of those with a disability (Kjellmer, 1986; Eckert \& McConnell-Ginet, 2003; Pearce, 2008; Vefali \& Erdentuğ, 2010; Hankivsky, 2013; Taylor, 2013; Moon, 2014; Baker, 2014).

The studies and research conducted in the last few decades indicate that there are several reasons why corpora should be used. The most obvious one is that the text contained in a corpus is a primary source. Taking into consideration the importance of authenticity to determine the value of linguistic research (Gee, 2011b), the analysis of linguistic data could benefit from a direct approach to the source material. Corpus linguistics studies are based on two principles: the first to the fact that the analysis should be independent, and the second to the significance of the linguistics features analysed (Stubb, 1996). Moreover, a corpus enables seeing key variations in the frequency of words and structures of texts, giving us significant insights on its semantic prosody, i.e. the context in which the text is created (Baker, 2006). The above-mentioned characteristics have been taken into consideration for this research, together with the basic features that a corpus should have to be differentiated from a simple collection of texts in an electronic format: in fact, a corpus should include a broad range of material to guarantee representativeness and, at the same time, be of a sufficient size (Sinclair, 2009).

Although there is currently a broad availability of resources on the European acquis in different corpora (Baisa, Michelfeit, Medved \& Jakubíček, 2016; Steinberger et al. 2013), this paper is focused on the legal provisions and rules related to the management of human resources currently in force in the EU institutions. For this reason, a specific corpus was created, containing all the currently applicable staff rules for civil servants working for the $\mathrm{EU}$ and its institutions: it consists of 58 documents (covering 47 subject matters), and it includes different types of legal provisions. The corpus has been named the EU HRM Legal Corpus. 
The most important document, including from a legal point of view, as mentioned in the preliminary analysis, is the Staff Regulation of Officials and Condition of Employment of Other Servants: this legal text is the basis of the legal framework of the management of staff resources in the EU institutions. It consists of two parts: the Staff Regulations (SR), which applies to officials, and the Condition of Employment of Other Servants, which applies to temporary and contract staff. ${ }^{1}$ The regulations were first published in June 1962; the consolidated text, including Staff Regulations and Condition of Employment of Other Servants, has been amended 142 times and corrected 25 times in the last 57 years. There were two major recent amendments, in May 2004 and January 2014, and both entailed a restructuring of the career path in the EU institutions and more modern working conditions (with the inclusion of improved work-life balance policies, such as flexitime, teleworking, etc.).

The Staff Regulations are composed of nine titles: general provisions, rights and obligations, career, working conditions, emoluments and social security, disciplinary procedures, appeals, special provisions, and transitional measures. The consolidated version of the text is also complemented by eleven annexes, which regulates in many details the different topics enshrined in the Staff Regulations, concerning selection and recruitment, leave and time management, type of posts, individual rights and monetary entitlements and pension contributions. The Conditions of Employment of Other Servants is divided according to the different contractual categories: temporary staff, contract staff, special advisers, and parliamentary assistants. The text heavily refers and points to the Staff Regulations in most of its parts, linking the different legal provisions by subject matter.

Together with the Staff Regulations and Condition of Employment of Other Servants, the corpus includes 57 implementing provisions of the Staff Regulations, and these implementing provisions give voice to the different rules applicable in the Staff Regulations and Condition of Employment of Other Servants. In different instances, the main regulations refer to the implementation of the acts by the adoption of implementing provisions. Their subject matter ranges from technical matters (calculation of pension contributions) to general ones (leave and time management); some of the implementing provisions are in fact staff policies, such as the policy for protecting the dignity of people and combatting psychological and sexual harassment.

Because of the decision to analyse the language patterns of the EU HRM Legal Corpus from a hybrid approach (corpus-based and corpus-driven), considerations were given to the filters and language features to examine by running queries through the corpus in AntConc (Anthony, 2013a and 2013b). In particular, the following language features are analysed in this research: word list by frequency, concordances (key word in context, KWIC), collocates and lexical bundles. Lower- and uppercase forms of all lemmas analysed have been taken into consideration in the overall results.

$1 \quad$ It is worth mentioning that there are several contractual categories of civil servants working for the EU institutions. While officials account for most of the European Commission's workforce, in agencies temporary and contract staff compose the vast majority. 
What appeared at the beginning of this research was the need to find a standard or example on the use of inclusive language, which is necessary to establish a frame against which the analysis of language patterns can be performed. The decision was made to use the EU Charter of Fundamental Rights, as this choice seems to be the most logical one, since the objective of the research is to unravel the understanding and application of equality and diversity principles in the EU staff rules. In other words, this research aims to analyse the EU HRM legal texts through the lens of the main legal text in terms of equality and diversity, i.e. the EU Charter of Fundamental Rights, as there is no better text to set the principles upon which the inclusive language of EU institutions should be based and be assessed. It is to be noted though that the aim of the various texts in the EU HRM Legal Corpus is rather different from that of the EU Charter of Fundamental Rights, and this needs to be taken into consideration in the analysis. Another aspect to take into account is the fact that the EU Charter of Fundamental Rights is used as a basis and at the same time as a reference.

With regard to the linguistic features analysed, this research started with the investigation of the word lists by frequency. According to Baker (2006: 47), "Frequency is one of the most central concepts underpinning the analysis of corpora". In particular, word lists by frequency are lists of tokens, which are grouped by frequency of occurrence in a given corpus. As described above, this is of particular relevance for this paper, as this research entails the development of word lists by frequency to compare the keywords in both the EU HRM Legal Corpus and EU Charter of Fundamental Rights. The aim is twofold, as it allows determining in the first place the expressions that are most represented in terms of frequency in the Charter, and in the second place it serves the purpose of analysing the presence and frequency of these terms in the EU HRM Legal Corpus. With regard to the analysis of the different terms, statistical significance was not included in the research, as the corpus comprises all the rules related to the management of human resources in the context of the EU institutions.

It was to be expected that some of the most used words in both texts would be in line with the genre of the documents. However, at the same time, it is particularly interesting to see the differences in the number of instances in certain semantic fields, as described in the following paragraphs. When considering the words linked to the concept of the EU as a whole, as an entity which is aimed to be better than the sum of its parts, it becomes immediately clear that there are significant differences in the two word lists by frequency. The term 'European' is the $14^{\text {th }}$ most frequent word in the EU Charter of Fundamental Rights, with 36 occurrences, and the $36^{\text {th }}$ most frequent word in the EU HRM Legal Corpus, with 646 occurrences. To compare the frequency in a more significant way, the hits have been normalised using a dispersion plot per one thousand hits. In this case, the term European in the EU Charter of Fundamental Rights has a dispersion value of 9.11, while in the EU HRM Legal Corpus its value is 2.98 .

Similar results in the same semantic area could be found for terms like 'Union' and 'Institution(s)'. For the first one the dispersion plot in the EU Charter of Fundamental 
Rights is 20.75, while in the Corpus is 2.24 , for 'Institution(s)', the dispersion plot in the EU Charter of Fundamental Rights is 2.02 and, in the EU HRM Legal Corpus, is 1.70. This is due to the different genre of the texts since not all the keywords that appear in the EU Charter of Fundamental Rights can be found in the EU HRM Legal Corpus. Although the analysis of the KWIC shows already that the number of references to 'European' are not as high as expected, since they are the implementing provisions aimed to foster internal working provisions for EU civil servants. The comparison with the EU Charter of Fundamental Rights shows that the terminology that most directly refers to the principle of 'European' is not developed in the EU HRM Legal Corpus to an extent that the genre of the corpus itself (i.e. prescriptive legal) would not justify. This has to be considered in the context that the first identification with the European values stems from a language that could most directly link them to the EU civil servants, as much as the EU Charter of Fundamental Rights of the European Union links it to EU citizens.

The linguistic analysis continued with the examination of the corpus' concordances. According to Baker (2006), a concordance is simply a list of all the occurrences of a particular search term in a corpus that is presented within the contexts where they occur. Each occurrence (or hit) found in a corpus is displayed in the analysis tool with the words preceding and following it. The most commonly used concordance type is called KWIC (Crawford \& Csomay, 2016). In the analysis conducted with AntConc, the results usually show one hit per line one the screen, with the main searched term highlighted in the centre. The overview of KWIC is an important part of this corpus research, as it gives a precise idea of the different features of the language used in the EU HRM Legal Corpus (Gabrielatos, 2018).

In a similar way to the approach used for the word list by frequency, the methodology used to analyse concordances and KWIC entails filtering the EU HRM Legal Corpus through the lens of the EU Charter of Fundamental Rights. In this context, lemmatisation or stemming was not considered, but rather the presence of keywords included in the EU Charter of Fundamental Rights vis-à-vis those present in the EU HRM Legal Corpus.

By looking into how the EU Charter of Fundamental Rights as divided into chapters touches upon the different aspects of equality and diversity, this research aims at running the concordances function in AntConc for the main terms included in each of the EU Charter's chapters. Alongside the preamble, the EU Charter of Fundamental Rights is divided into seven different titles:

$\begin{array}{ll}\text { TITLE I } & \text { DIGNITY } \\ \text { TITLE II } & \text { FREEDOMS } \\ \text { TITLE III } & \text { EQUALITY } \\ \text { TITLE IV } & \text { SOLIDARITY } \\ \text { TITLE V } & \text { CITIZENS' RIGHTS } \\ \text { TITLE VI } & \text { JUSTICE } \\ \text { TITLE VII } & \text { GENERAL PROVISIONS GOVERNING THE INTERPRETATION } \\ & \text { AND APPLICATION OF THE CHARTER }\end{array}$


In the context of this paper, the titles that are most relevant for the aim of this research on the language of equality and diversity are those included in Title III - Equality. Alongside this choice of scope, additional considerations were given to some general parts of the EU Charter of Fundamental Rights regarding the topics analysed, in particular for features related to the European institutions and their correct functioning, according to the European principles of transparency and good administrative behaviour. A complete matrix of the keywords that served as a basis for the analysis, together with the different chapters of the EU Charter of Fundamental Rights, is presented in Table 1.

Table 1: List of KWIC related to different areas of equality and diversity analysed in the EU HRM Legal Corpus

\begin{tabular}{|c|c|c|}
\hline FOCUS & $\begin{array}{l}\text { EU CHARTER OF } \\
\text { FUNDAMENTAL RIGHTS }\end{array}$ & KEYWORDS \\
\hline $\begin{array}{l}\text { GENERAL EQUALITY } \\
\text { AND DIVERSITY } \\
\text { TERMINOLOGY }\end{array}$ & PREAMBLE & $\begin{array}{l}\text { dignity, integrity, human, security, privacy, } \\
\text { personal data, respect / respected, people, } \\
\text { person/persons }\end{array}$ \\
\hline LGBTI & $\begin{array}{l}\text { Title III - Equality } \\
\text { Article } 9\end{array}$ & $\begin{array}{l}\text { civil marriage, same-sex marriage, non- } \\
\text { marital / non marital partner / partnership, } \\
\text { spouse, wife / husband }\end{array}$ \\
\hline $\begin{array}{l}\text { EU EQUALITY } \\
\text { PRINCIPLES }\end{array}$ & $\begin{array}{l}\text { Title III - Equality } \\
\text { Articles 20, 21, } 22\end{array}$ & $\begin{array}{l}\text { non-discrimination equality, equal } \\
\text { opportunities, diversity, inclusion, work- } \\
\text { life, religion / religious, cultural, linguistic }\end{array}$ \\
\hline GENDER & $\begin{array}{l}\text { Title III - Equality } \\
\text { Article } 23\end{array}$ & $\begin{array}{l}\text { sex / sexual, gender, men / women, he, she, } \\
\text { he or she, he/she, she/he, him, her, him/ } \\
\text { her, him or her, his, her, hers, his/her, his or } \\
\text { her, they, chairman }\end{array}$ \\
\hline ELDERLY STAFF & $\begin{array}{l}\text { Title III - Equality } \\
\text { Article } 25\end{array}$ & elderly, retired, old, young \\
\hline $\begin{array}{l}\text { PERSON(S) WITH } \\
\text { A DISABILITY }\end{array}$ & $\begin{array}{l}\text { Title III - Equality } \\
\text { Article } 26\end{array}$ & $\begin{array}{l}\text { handicap, disabled, } \\
\text { (with a) disability }\end{array}$ \\
\hline $\begin{array}{l}\text { OTHER TERMS RELATED } \\
\text { TO EU INSTITUTIONS }\end{array}$ & GENERAL & $\begin{array}{l}\text { good administration, impartiality, fairness, } \\
\text { proportionality, reasonable time, right to } \\
\text { be heard, access to, reasoned }\end{array}$ \\
\hline
\end{tabular}

Using AntConc, a concordance hit list in the EU HRM Legal Corpus, considering a span of -5 and +5 words, was run for each of the keywords included in Table 4 . With regard to the Preamble of the EU Charter of Fundamental Rights, containing terms related to general equality and diversity principles, the KWIC analysed are the following: 'dignity', 'integrity', 'human', 'security', 'privacy', 'personal data', 'respect', with the variations of 'respected' and the terminology related to 'people', 'person' and 'persons'

Following the same methodology of filtering the EU HRM Legal Corpus with the keywords included in the EU Charter of Fundamental Rights, this research started with the analysis of some keywords within their contexts and focused on the collocates of 
the word 'European'. The preliminary findings of the use of such terms in the EU HRM Legal Corpus, in particular the findings of the word list by frequency analysis, have been validated fully, to the extent that 'European' seems not to be a keyword in the EU HRM Legal Corpus, as the term collocated only with words linked to the different institutions. Significantly, the term does not collocate in any meaningful way with other parts of the text in the corpus. It is indeed quite surprising that the value of being European is not embedded in the internal policies that are aimed to regulate the life of EU civil servants (see Table 5). It is of particular interest to notice that previous studies on the collocation of the term 'European' in a corpus similar in size to the EU HRM Legal Corpus, albeit not closely related to legal provisions of EU civil servants, revealed a much higher occurrence of the term 'European' (Trebits, 2008). The difference in genre of the two corpora may explain the different frequency of the term 'European', but surely not to the extent shown by this research.

Another linguistic feature analysed in this study relates to the presence of lexical bundles in the corpus. By running a frequency count of lexical bundles with AntConc, it was found out that the recurrent significant bundles are related to legal terms and references that are in line with the genre of the texts included in the EU Legal Corpus, such as, for example, the bundles 'staff regulation' and 'appointing authority'. Another interesting feature, typical of legalese, is the use of modifiers such as 'same', 'said', 'above-mentioned'. In the EU HRM Legal Corpus, it is interesting that these are frequently used as adjectives to further determine and reinforce nouns, not replace them. There are different examples in the corpus, in particular 'said amount' and 'said condition(s)'. These modifiers convey a message of redundancy in the texts of the EU HRM Legal Corpus, limiting the fluidity of the language and the ease of reading the different rules and provisions.

It is interesting to note that none of the other terms related to inclusive language as analysed in this dissertation is in any bundle of the first 100-frequency list, as shown in Table 11. This may be due to the legal and administrative genre of the EU HRM Legal Corpus, but it may also suggest that the frequency of equality and diversity terminology, for example with bundles like 'work-life balance' and 'person with a disability', is not present in the corpus.

However, a deeper analysis of the data, after applying the same methodology of filtering the Corpus with the KWIC in the EU Charter of Fundamental Rights, allows us to identify two outcomes of the lexical bundle analysis which are of interest for this research, i.e. the terms from the list of keywords in the Charter (see Table 4) which relate to the semantic field 'Europe' and 'European'. These terms are of particular importance vis-à-vis the identified necessity to highlight the European dimension of the language in the corpus, and in particular for what concerns fostering EU values, such as inclusion and non-discrimination. The principles of equality and diversity are already part of the treaties founding the EU, and in particular are spelt out as values in Article 2 of the Treaty on European Union: 
The Union is founded on the values of respect for human dignity, freedom, democracy, equality, the rule of law and respect for human rights, including the rights of persons belonging to minorities. These values are common to the Member States in a society in which pluralism, non-discrimination, tolerance, justice, solidarity and equality between women and men prevail. (European Council, 2016, p. 17)

The analysis of the lexical bundles including the term 'European' is thus relevant to seek links to the EU values and their implementation in the EU HRM Legal Corpus. Concerning the term 'European', it is number 19 on the frequency list, albeit it is only linked to the pronoun 'the', while the bundle 'European Union' is number 46 on the list. A more detailed analysis of the term 'European' shows that it appears in a cluster with 'Union' more than with 'Commission'. This finding has a rather simple explanation, considering that the preambles of many implementing provisions quote a general introductory sentence, which reads: "Having regard to the Treaty on the Functioning of the European Union", while the link of 'European' to 'Commission' is mainly due to the reference to the workplace the EU HRM Legal Corpus applies to.

Furthermore, of particular importance for this research is the presence of the lexical bundle 'of his' in the first $100 \mathrm{~N}$-Grams of the corpus. This, once again, suggests a higher frequency of the generic masculine, which is not considered a gender-neutral expression. In particular, this linguistic use creates a prototypical image of an EU staff member as male, and to the creation of a null gender, which means assuming that the default and standard gender is male and not female. This is because masculine forms, even when they are used in a generic sense, usually activate male representations (Fuertes-Olivera, 2007; Wagner, Garcia, Jadidi \& Strohmaier, 2015).

The result of this analysis of the corpus shows that no meaningful lexical bundles are present in the EU HRM Legal Corpus suggesting the use of inclusive language. No lexical bundles were found that are significant for the analysis of the use of a language that fosters equality and diversity in the EU institutions, while the biased use of the English language in the corpus appears obvious.

\section{3}

\section{RESEARCH FINDINGS}

Looking into the findings of the EU HRM Legal Corpus Linguistics analysis, it seems that, although some positive language shifts are happening, much improvement remains to be made. The first highlight of the paper concerning its findings is that the terms ' $\mathrm{Eu}-$ rope' and 'European', as an embedded value to the different staff provisions and rules, are difficult to find in the EU HRM Legal Corpus. While the preambles of the different legal basis strive to give a context to the different rules, this seems to be more linked to the aim 
of passing a message of contemporary human resources management than to embed the values that stand behind the EU.

This static feature of the EU internal legal language can also be seen when looking into the general principles of equality, as introduced in the preamble of the EU Charter of Fundamental Rights. The main highlight at this point of the research shows that the concepts of persons, their security and personal data, are not reflected in the corpus to the same extent that they are in EU policies, and while this could only be done to a lesser extent, such concepts could have been included nonetheless.

With regard to the awareness and inclusion of LGBTI persons, it appears even more clearly that the diversity that is the enriching part of the EU philosophy fails to appear in the EU HRM Legal Corpus. For example, while defining that a non-marital partnership is compared to marriage when it comes to the application of entitlements in the Staff Regulations, a more cohesive use of the language might reinforce the principle of equality in dealing with these different statuses and change the mindset of the civil servants who are all affected by these regulations. At the same time though, in this instance it should be noted that a diachronic dimension of evolution in the language is present in the corpus. More attention being paid to the terminology related to partnership and the evolution of this concept will foster a better LGBTI inclusion, although it should be noted that, when it comes to gender mainstreaming, the EU internal provisions are for now only developing in a dichotomic direction (male-female), and do not include any element of intersectionality (Hankivsky, 2013; Hord, 2016).

The area in which a greater effort has been made to create awareness and equality in the workplace is that related to gender. A broad campaign on gender mainstreaming, which is currently taking place in all Commission services, is probably bearing its fruits in term of the use of a more inclusive language. Gender equality is the part of the EU HRM Legal Corpus where explicit sentences are included in the different rules.

Unfortunately, though, a deeper analysis of the use of gender-related possessives and pronouns shows that there is still a long way to go to embed the concept of equal treatment for men and women. Although in different instances the language does make use of feminine possessives or pronouns, the caveat in the Staff Regulations that states that, "Any reference in these Staff Regulations to a person of the male sex shall be deemed also to constitute a reference to a person of the female sex" should be overcome. It is particularly important to strive for a better wording in such contexts. Although the caveat is specified at the beginning of the Staff Regulations, in many instances provisions such as "he is promoted" can be encountered. This does not foster the idea behind gender equality, and contributes to the distorted identity building of Staff Members working for the institutions (Holmes, 2015; Searle, 2015).

This issue is of particular importance to overcome the concept of male as a "null gender", as assuming that the default and standard gender is male and not female contributes to reinforcing the typical gender stereotype (Fuertes-Olivera, 2007; Wagner, Garcia, Jadidi \& Strohmaier, 2015). 
Other sensitive wording that is used in the Staff Regulations should be more genderneutral. For example, the use of chairman instead of chairperson can be found 47 times in the EU HRM Legal Corpus, mainly in the Staff Regulations. Again, the shift in the language of more recent provisions is present, although gender mainstreaming perhaps has benefits with regard to increased consistency and possibly bolder changes in the revision of the language used in older texts. It should be noted though that the language of the two corpora is still far from complying with the definition of gender-sensitive language, as defined by the European Institute for Gender Equality on its website2:

The realisation of gender equality in written and spoken language attained when women and men and those who do not conform to the binary gender system are made visible and addressed in language as persons of equal value, dignity, integrity and respect.

Avoiding sex- and gender-based discrimination starts with language, as the systematic use of gender-biased terminology influences attitudes and expectations and could, in the mind of the reader or listener, relegate women to the background or help perpetuate a stereotyped view of women's and men's roles. There are numbers of different strategies that can be used to express gender relationships with accuracy, such as avoiding, to the greatest possible extent, the use of language that refers explicitly or implicitly to only one gender, and ensuring, through inclusionary alternatives and according to each language's characteristics, the use of gender-sensitive and inclusive language. (EIGE, 2019)

With regard to the awareness and inclusion of persons with a disability, the research shows that much still needs to be done concerning the use of inclusive language in the EU HRM Legal Corpus. The terms 'disabled' and 'handicapped' still appear in the texts of the EU HRM Legal Corpus. The 2006 UN Convention on the Rights of Persons with Disabilities refers to a person with a disability instead of a disabled person to stress that a person is not disabled but has a disability. The convention has been signed by all $28 \mathrm{EU}$ Member States, and so far has been ratified by 25 . In 2010, the WU also ratified the Convention, and it plays a leading role in the monitoring framework for implementing it among EU institutions. The definition of a person with a disability in the UN Convention is as follows:

Persons with disabilities include those who have long-term physical, mental, intellectual or sensory impairments, which in interaction with various barriers may hinder their full and effective participation in society on an equal basis with others. (UN General Assembly. 2007). 
This wording is deemed fundamental to changing the attitudes of people without a disability, and although the Staff Regulations takes this definition on board and includes it in Article 1d, in the following articles the term 'disabled people' still occurs five times in the consolidated version of the text.

The same conclusions could be drawn for the area of fundamental rights that relate to elderly persons. Although it seems clear that the Staff Regulations and its implementing provisions are aimed to regulate a rather specific target age group, and that the genre of the corpus embeds a different aim with regard to this issue, some improvements could be made to avoid terms such as 'young' and encourage a narrative of inclusion of all staff members in all ages groups.

Looking now into the terminology which relates to the principle of good administration, it seems from the results that more efforts could be made to include in the preambles of the various provisions - such as the one on recruitment or reclassification - terminology such as 'fairness' or 'proportionality'. Moreover, the concept of 'reasonable time' is reversed in relation to the meaning of the EU Charter of Fundamental Rights. Instead of the administrative bodies being asked to be reasonable in dealing with various personal files in a timely manner, staff members are those left with this responsibility.

\section{4}

\section{CONCLUSIONS}

EU institutions are nowadays well aware and informed on the language of human rights and non-discrimination principles, and affirmative actions in term of equality, although mostly related to gender than to ethnic minorities or persons with a disability, are being implemented in different organisations. Alongside considerations related to the legal basis of such action, some institutions are proactive in dealing with the issues of equality and diversity in the workplace, guaranteeing equal participation and shared responsibilities in contexts such as internal directives and policymaking. The question this research examined was whether this awareness of the principle of equality and diversity is embedded in the most fundamental basis of the regulatory framework for staff members of the different institutions, the Staff Regulations and their implementation provisions.

The discourse around the principles of equality and diversity cannot transcend an appropriate use of language, and this is especially the case inside any international organisation with a key leading role in Europe, such as EU institutions. Language is not only a reflection of society, it is an instrument to actively build the social reality thorough discourse (Fairclough, 2001), this is because language not only reflects interpersonal behavioural patterns, but creates and defines them. As such,: any bias in the use of language has direct implications for equal opportunities for both the civil servants working in such institutions, and the wider community of EU citizens. 


\section{BIBLIOGRAPHY}

ALVESSON, Mats/Dan KARREMAN (2000) Varieties of Discourse: on the study of organizations through Discourse Analysis, Human Relations Vol. 53(9), 1125-1149.

ANTHONY, Lawrence (2013a) Developing AntConc for a new generation of corpus linguists. Proceedings of the Corpus Linguistics Conference (CL 2013), July 22-26, 2013. Lancaster University, 14-16.

ANTHONY, Lawrence (2013b) A critical look at software tools in corpus linguistics. Linguistic Research Vol. 30(2), 141-161.

BAISA, Vít/Jan MICHELFEIT/Marek MEDVEĎ/Miloš JAKUBÍČEK (2016) European Union Language Resources in Sketch Engine. In The Proceedings of Tenth International Conference on Language Resources and Evaluation (LREC'16). European Language Resources Association (ELRA). Portorož, Slovenia. Available at: https://www. sketchengine.eu/wp-content/uploads/eur_lex_2016.pdf [Accessed on 15 May 2020].

BAKER, Paul (2005) Public Discourses of gay men. London: Routledge.

BAKER, Paul (2006) Using Corpora in Discourse Analysis. London: Continuum.

BAKER, Paul (2010) Sociolinguistics and Corpus Linguistics. Edinburg: Edinburg University Press.

BAKER, Paul (2014) Using corpora to analyse gender. London: Bloomsbury.

BAKER, Paul (2018) Language, sexuality and corpus linguistics. In Motschenbacher, H. (Ed.) Corpus linguistics in language and sexuality studies: developments and prospects, Journal of Language and Sexuality, Vol. 7(2), 263-279. DOI: 10.1075/ jls.17018.bak.

BARONE, Linda (2005) La lingua inglese delle istituzioni europee: standardizzazione, armonizzazione o approssimazione? Salerno: Laveglia.

BHATIA, Vijay (1983) Simplification vs easification: the case of legal texts. Applied Linguistics, Vol. 4(1), 42-54.

BHATIA, Vijay (1993) Analysing genre: language use in professional setting. London: Longman.

BRÉDA, Cathy/Miguel DELATTRE/Rodolphe OCLER (2008) The story behind identities: from corporate discourse to individual recognition. Tamara journal of critical postmodern organization science, Vol.7 (1). Warsaw: Kozminski University.

BREIDBACH, Stephan (2003) Plurilingualism, democratic citizenship in Europe and the role of English. Strasbourg: Council of Europe. Available at: http://www.coe. int/. [Accessed 15 May 2020].

CENOZ, Jasone (2013) Defining Multilingualism. Annual Review of Applied Linguistics, Vol. 33, 3-18. DOI: 10.1017/S026719051300007X.

COOREN, François (2004) Textual agency: how texts do things in organizational settings. SAGE Journals, Vol. 11(3). London: Sage.

CRAWFORD, Williams/Eniko CSOMAY (2016) Doing Corpus Linguistics. New York: Routledge. 
ECKERT, Penelope/Sally MCCONNELL-GINET (2003) Language and Gender. New York: Cambridge University Press.

EDWARD, John (2009) Language and identity: an introduction. Cambridge: Cambridge University Press.

European Council (1962). Regulation no 31 (EEC), 11 (EAEC), laying down the Staff Regulations of Officials and the Conditions of Employment of Other Servants of the European Economic Community and the European Atomic Energy Community. Luxembourg: Publications Office of the European Union.

European Parliament (2000). Charter of Fundamental Rights of the European Union. Luxembourg: Publications Office of the European Union.

FUERTES-OLIVERA, Pedro (2007) A corpus-based view of lexical gender in written Business English. English for Specific Purposes Vol. 26, 219-234. DOI: 10.1016/j. esp.2006.07.001.

GABRIELATOS, Costas (2018) Keyness Analysis: nature, metrics and techniques. In Taylor, C. \& Marchi, A. (Ed.), Corpus approaches to discourse: a critical review. Oxford: Routledge.

GIBOVÁ, Klaudia (2011) On modality in EU institutional-legal texts in Kačmárová, A. (Ed.) English Matters II, 6-12. Prešov: Prešovská Univerzita.

GRUE, Jan (2014). Disability and discourse analysis. London: Routledge.

KJELLMER, Göran (1986) 'The lesser man': observations on the role of women in modern English writing. In Arts, J. \& Meijs, W. (Ed.), Corpus Linguistics II, 163176. Amsterdam: Rodopi.

HATCH, Mary Jo/ Ann CUNLIFFE (2006) Organization theory: modern, symbolic, and postmodern perspectives. Oxford: Oxford University Press.

HANKIVSKY, Olena (2013) The lexicon of mainstreaming equality: Gender-Based Analysis (GBA), Gender and Diversity Analysis (GDA) and Intersectionality Based Analysis (IBA). Canadian Political Science Review, Vol. 6(2-3), 171-183. Available at: https://ojs.unbc.ca/index.php/cpsr/article/view/278. [Accessed on 15 May 2020].

HYLAND, Ken/Meng HUAT/Micheal HANDFORD (2012) Corpus applications in applied linguistics. London: Continuum.

HOLMES, Janet (2015) Discourse in the Workplace. In Schiffrin, D., Tannen, D. \& Hamilton, H.E. (Ed.), The handbook of Discourse Analysis, Second Edition. Hoboken: Wiley Online Library. DOI: 10.1002/9781118584194.ch41.

HORD, Levi (2016) Bucking the linguistic binary: gender-neutral language in English, Swedish, French, and German. Western Papers in Linguistics / Cahiers linguistiques de Western Vol. 3(4). Available at: https://ir.lib.uwo.ca/wpl_clw/vol3/iss1/4 [Accessed on 15 May 2020].

HUMMERT, Mary-Lee/Teri GARSTKA/ Ellen RYAN/ Jaye BONNESEN (2004) The role of age stereotypes in interpersonal communication. In Nussbaum J. F. \& Harwood J. (Ed.) The Handbook of Communication and Aging, 91-114. Mahwah: Lawrence Erlbaum Associates. 
HUNSTON, Susan (2002) Corpora in applied linguistics. Cambridge: Cambridge University Press.

MANUTI, Amelia/ Giuseppe MINNINI (2015) Analysing human resource managers' discourse on diversity: a study in some Italian small and medium enterprises. Psicoperspectivas Vol. 14(1), 126-136. Valparaíso: Pontificia Universidad Católica de Valparaíso.

MAUTNER, Gerlinde (2007) Mining large corpora for social information: the case of elderly. Language in Society Vol. 36(1), 51-72. DOI:10.1017/S0047404507070030.

MORGAN, Gareth (2006) Images of Organization. London: Sage.

MARMOR, Andrei (2008) The pragmatics of legal language. Ratio Juris, Vol 21(4), 423-452. Hoboken: Wiley-Blackwell. DOI: 10.1111/j.1467-9337.2008.00400.x.

MAUREL, Olivier (2008) La responsabilité des entreprises en matiere de droits de l'homme. Paris: Documentation Française.

MOON, Rosamund (2014) From gorgeous to grumpy: adjectives, age, and gender. Gender and language Vol. 8(1), 8-41. DOI: 10.1558/genl.v8i1.5.

PEARCE, Michael (2008) Investigating the collocational behaviour of man and woman in the BNC using Sketch Engine. Corpora Vol. 3(1). 1-29. DOI: 10.3366/ E174950320800004X.

SEARLE, John (1995) The construction of social reality. New York: The Free Press.

SINCLAIR, John (1997) Corpus, concordance, collocation. Oxford: Oxford University Press.

STEINBERGER, Ralph/Mohamed EBRAHIM/Alexandros POULIS/Manuel CARRASCO-BENITEZ/Patrick SCHLÜTER/Marek PRZYBYSZEWSKI/Signe GILBRO (2013) An overview of the European Union's highly multilingual parallel corpora. Journal Language Resources and Evaluation Vol. 48(4), 679-707. DOI: 10.1007/ s10579-014-9277-0.

STUBB, Michael (1996) Text and Corpus Analysis. London: Blackwell.

STUBB, Michael (2001) Words and phrases: corpus studies of lexical semantics. London: Blackwell.

TATLI, Ahu (2011) A multi-layered exploration of the diversity management field: diversity discourses. British Journal of Management Vol. 22, 238-253. Hoboken: Wiley Online Library. DOI: 10.1111/j.1467-8551.2010.00730.x.

TAYLOR, Charlotte (2013) Searching for similarity using corpus-assisted discourse studies. Corpora Vol. 8(1), 81-113. DOI: 10.3366/cor.2013.0035.

TREBITS, Anna (2008) English lexis in the documents of the EU: a corpus-based exploratory study. Working Papers in Language Pedagogy 2, 38-54. Available at: http:// langped.elte.hu/WoPaLParticles/W2Trebits.pdf [Accessed on 15 May 2020].

VEFALI, Gülşen Musayeva/ Fulya ERDENTUĞ (2010) The coordinate structures in a corpus of New Age talks: 'man and woman'/“woman and man'. Text \& Talk-an interdisciplinary journal of language, discourse \& communication studies Vol. 30(4), 465-484. DOI: 10.1515/TEXT.2010.023. 
WAGNER, Claudia/David GARCIA/Mohsen JADIDI/Markus STROHMAIER (2015) It's a Man's Wikipedia? Assessing gender inequality in an online encyclopaedia. In Proceedings of the Ninth International AAAI Conference on Web and Social Media. Available at: https://pdfs.semanticscholar.org/05e1/0638aab94ca0d46ddde8083ff69 859a0401e.pdf [Accessed on 15 May 2020].

\section{POVZETEK}

\section{UPRAVLJANJE Z ENAKOSTJO IN RAZNOLIKOSTJO V INSTITUCIJAH EVROPSKE UNIJE: KORPUSNA ANALIZA JEZIKA V PRAVNIH BESEDILIH S PODROČJA UPRA- VLJANJA S ČLOVEŠKIMI VIRI}

Cilj prispevka je analizirati pravni okvir, ki ureja položaj javnih uslužbencev v institucijah Evropske unije, ter prikazati, kako sta enakost in raznolikost predstavljeni in vključeni v vsakdanjik tamkajšnjih javnih uslužbencev. V raziskavi smo preučili rabo angleškega jezika v pravnih besedilih s področja upravljanja s človeškimi viri v evropskih institucijah. Podrobneje smo analizirali jezikovne vidike, povezane z upravljanjem enakosti in raznolikosti, in vključujočo rabo jezika.

Raziskavo smo umestili v okvir evropske zibelke enakosti in raznolikosti - Evropske unije, ki se izrazito opira na demokratične vrednote, vladavino prava in enako obravnavo vseh prebivalcev, katerih raznolikost predstavlja kot posebno vrednoto. Pomembno je torej, da ugotovimo, kako Evropska unija deluje v praksi ter kako dosledna je pri razumevanju in uveljavljanju omenjenih vrednot.

Metodološki pristop naše raziskave je zahteval oblikovanje in analizo edinstvenega korpusa, v katerem so bile zbrane vse trenutno veljavne zakonske določbe, ki urejajo položaj človeških virov v evropskih institucijah. Da bi preučili razvoj rabe angleškega jezika na področju enakosti in raznolikosti, smo s pomočjo korpusa analizirali jezikovne prvine (pogostost rabe izrazov, konkordance, kolokacije in leksikalne skupe) terminoloških leksikalnih enot, povezanih s štirimi različnimi področji: LGBTI, spol, starejši in osebe z oviranostmi.

Rezultati raziskave kažejo, da jezik v pravnih besedilih Evropske unije s področja upravljanja s človeškimi viri ni skladen z evropskima vrednotama enakosti in raznolikosti. V prispevku zato na koncu predlagamo možne izboljšave v rabi jezika, ki smo ga preučili v korpusu.

Ključne besede: korpusno jezikoslovje, upravljanje s človeškimi viri, evropske institucije, enakost in raznolikost 


\section{ABSTRACT}

The aim of this paper is to analyse the legal framework regulating the careers of civil servants working for the EU institutions and reveal how the values of equality and diversity are communicated and embedded in their daily lives. The research examines the English language used in the HR legal framework of the EU institutions and explores the linguistic aspects related to equality and diversity management and inclusive language.

The starting point of this research is the idea that the European Union is based on the values of democracy, the rules of law and the equal treatment of its citizen, who are celebrated for their diversity. It is thus highly relevant to look at the EU in action and see if it is consistent in the understanding and application of these values.

The methodological approach of this research entailed the creation and analysis of a unique corpus composed of all the applicable HR legal provisions in force within the EU institutions, and the examination of the linguistic features (word lists by frequency, concordances, collocations and lexical bundles) of the terminology related to four different areas of equality and diversity - the LGBTI community, gender, the elderly and persons with a disability - with the final aim to take stock of the related developments in the use of the English language.

The results indicate that the language used in the EU HRM legal framework is not in line with the EU values of equality and diversity, and the research concludes with highlighting possible improvements of the language used in the corpus.

Keywords: Corpus Linguistics, Human Resources Management, European Institutions, Equality and Diversity 